\title{
Model Petri Net Sistem Pembayaran Pajak Kendaraan Bermotor Jenis 5 Tahun
}

\author{
Nurlela' ${ }^{1}$ Ahmad Faisol2 ${ }^{*}$, Fitriani $^{3}$ \\ 1,2,3 Jurusan Matematika, Fakultas MIPA, Universitas Lampung, \\ Jl. Prof. Sumantri Brojonegoro No. 01 Gedong Meneng, Bandar Lampung, 35145, Indonesia \\ * Penulis Korespondensi. Email: ahmadfaisol@fmipa.unila.ac.id
}

\section{ABSTRAK}

Pembayaran pajak merupakan salah satu contoh pelayanan publik. Dalam proses pelayannya sering kali identik dengan adanya proses antrian. Antrian merupakan kondisi beberapa orang atau benda yang membentuk suatu garis tunggu untuk dilayani yang disebabkan oleh kebutuhan layanan melebihi kapasitas pelayanan atau fasilitas layanan. Untuk mengatasi terjadinya banyak keluhan akibat antrian dapat dilakukan dengan cara meningkatkan pelayanan dan memaksimalkan efisiensi waktu yaitu dengan menggunakan model Petri Net. Pada penelitian ini dibuat model Petri Net sistem pelayanan pembayaran pajak kendaraan bermotor jenis 5 tahun di SAMSAT Oku Timur 1 sebanyak 17 places, 15 transisi, 2 operator, dan 30 arc dengan menggunakan softwere WOPED 3.2.0.

Kata Kunci:

Petri Net; Pemodelan; Model Antrian Pembayaran Pajak

\section{ABSTRACT}

Paying taxes is an example of public service. In the process of serving, the service is often synonymous with the queuing process. Queuing is a condition in which several people or objects from a waiting line to be served are generally caused by the need for services to exceed the service capacity or service facilities so that users of arriving facilities cannot immediately receive service. Therefore, overcoming many complaints due to queues can be done by improving services and maximizing time efficiency using the Petri net model. In this study, a Petri net model of the 5-year tax payment service system for a motor vehicle at SAMSAT Oku Timur 1 was made as many as 17 places, 15 transitions, two operators, and 30 arcs using WOPED 3.2.0 software.

Keywords:

Petri Net; Modeling; Tax Payment Queue Model

Format Sitasi:

N. Nurlela, A. Faisol, and F. Fitriani, "Model Petri Net Sistem Pembayaran Pajak Kendaraan Bermotor Jenis 5 Tahun," Jambura J. Math., vol. 4, no. 1, pp. 33-40, 2022, doi: https://doi.org/10.34312/jjom.v4i1.11158

\section{Pendahuluan}

Menurut UU No. 25 Tahun 2009, pelayanan publik adalah kegiatan atau rangkaian kegiatan dalam rangka pemenuhan kebutuhan pelayanan sesuai dengan peraturan

e-ISSN: 2656-1344 ( 2022 N. Nurlela, A. Faisol, F. Fitriani | Under the license CC BY-NC 4.0

Received: 6 July 2021 | Accepted: 13 September 2021 | Online: 1 January 2022 
perundang-undangan bagi setiap warga negara dan produk atau barang, jasa, dan atau pelayanan administratif yang disediakan oleh penyelenggara pelayanan publik [1].

Salah satu contoh pelayanan publik yaitu pembayaran pajak. Pajak merupakan salah satu pendapatan tertinggi suatu negara. Menurut Undang-Undang No. 16 Tahun 2009 tentang Ketentuan Umum dan Tata Cara Perpajakan, pajak adalah kontribusi wajib kepada negara yang terutang oleh orang atau badan yang bersifat memaksa berdasarkan undang-undang dengan tidak mendapatkan imbalan secara langsung dan digunakan untuk keperluan negara bagi sebesar-besarnya kemakmuran rakyat [2].

Dalam proses pelayanan publik seperti pembayaran pajak sering dijumpai adanya proses antrian. Antrian merupakan kondisi beberapa orang atau benda yang membentuk suatu garis tunggu untuk dilayani [3]. Umumnya antrian disebabkan karena kebutuhan layanan melebihi kapasitas pelayanan atau fasilitas layanan, sehingga pengguna fasilitas yang tiba tidak bisa segera mendapat layanan. Sering kali terjadi banyak keluhan akibat antrian yang terjadi cukup lama. Untuk mengurangi antrian dapat kita lakukan dengan cara meningkatkan pelayanan dan memaksimalkan efisiensi waktu. Salah satu caranya yaitu dengan menganalisis sistem pelayanan pembayaran pajak dengan menggunkan model Petri Net [4].

Petri Net adalah salah satu alat untuk memodelkan system event descrete [5]. Petri Net merupakan graph berarah [6] yang memiliki 2 node yang dinamakan Place dan Transisi. Arc dilambangkan dengan anak panah (arrow), Place dilambangkan sebagai lingkaran (circles) dan Transisi dilambangkan sebagai persegi panjang (bars). Arc secara tidak langsung menghubungkan place dengan place atau transisi dengan transisi, tetapi menghubungkan place dengan transisi atau transisi dengan place. Tiap place dapat berisi satu atau beberapa token yang dilambangkan dengan bulatan kecil (dots) yang merupakan material yang ditrasfer dalam satu sistem Petri Net [7].

Beberapa penelitian terkait penggunaan model Petri Net telah dilakukan oleh para peneliti sebelumnya. Pada bidang transportasi, penelitian terkait Petri Net dapat dilihat pada [8][9][10]. Pada bidang industri, penggunaaan model Petri Net dapat dilihat pada [11][12]. Di dalam [13][14][15], telah dikaji penerapan Petri Net pada bidang pertanian. Selanjutnya pada bidang geografi, penggunaan Petri Net juga dapat dilihat pada [16][17]. Di sisi lain, penerapan model Petri Net pada bidang E-Commerce diantaranya telah dikaji oleh Yu dkk. [18] serta Mitrevski dan Hristoski [19]. Sedangkan, penelitian ini merupakan penerapan model Petri Net pada bidang palayanan publik, khususnya sistem pembayaran pajak kendaraan. Pada penelitian ini diberikan model Petri Net sistem pembayaran pajak jenis 5 tahun yang dibentuk dengan perangkat lunak WOPED 3.2.0., dengan tujuan untuk membuat alur Petri Net SAMSAT Oku Timur 1.

\section{Metode}

Metode penelitian ini berupa studi literatur serta pengumpulan data tentang sistem pelayanan pembayaran pajak kendaraan tahunan. Pengambilan data dilakukan pada bulan Februari 2021 di Wilayah SAMSAT Oku Timur Wilayah 1, Jl. Adiwiyata Kotabaru Martapura Oku Timur, Provinsi Sumatera Selatan.

Hasil penelitian ini diperoleh dengan langkah-langkah sebagai berikut:

1. Membuat model Petri Net,

2. Melakukan simulasi menggunakan software WOPED 3.2.0 untuk memverifikasi 
dan memvalidasi model Petri Net,

3. Menentukan matriks representasi,

4. Menarik kesimpulan.

\section{Hasil dan Pembahasan}

Pada bagian ini dijelaskan mengenai model Petri Net untuk salah satu layanan publik yang melibatkan antrian. Salah satu contoh layanan publik yang dibuat sistemnya dengan menggunakan model Petri Net adalah sistem pelayanan pembayaran pajak kendaraan bermotor jenis 5 tahun di SAMSAT Oku Timur 1.

\subsection{Analisis Sistem Pelayanan Pembayaran Pajak Kendaraan Bermotor Jenis 5 Tahun di SAMSAT Oku Timur 1}

SAMSAT Oku Timur 1 memiliki dua loket pelayanan dan satu loket Bank Sumsel. Pada loket pelayanan satu terdiri dari lima orang petugas dari Bapenda, satu orang petugas kepolisian dan satu orang petugas Jasa Raharja. Loket pelayanan kedua terdiri dari lima orang petugas dari Bapenda. Bank Sumsel terdiri dari satu orang petugas Bank. Loket pelayanan bertugas untuk melayani pemeriksaan kelengkapan berkas wajib pajak, input data, pengoreksian, mencetak kutipan pembayaran pajak dan mencetak SKPD/STNK. Adapun Bank Sumsel bertugas untuk melayani wajib pajak yang akan melakukan pembayaran setelah semua proses terselesaikan.

Saat wajib pajak datang, petugas Bapenda di loket pelayanan 1 melakukan pemeriksaan kelengkapan berkas wajib pajak. Apabila berkas dinyatakan lengkap maka akan menuju tahap selanjutnya yaitu cek fisik kendaraan oleh petugas dari kepolisian. Setelah itu dilakukan input data dan juga pengecekan ranmor oleh petugas kepolisian. Selanjutnya petugas Bapenda mencetak kutipan pembayaran pajak yang nantinya akan diperiksa oleh petugas Bapenda. Lalu dilakukan pengecekan SWDKLLJ (Sumbangan Wajib Dana Kecelakaan Lalu Lintas Jalan) oleh petugas dari Jasa Raharja. Kemudian wajib pajak melakukan pembayaran di Bank Sumsel. Tahapan selanjutnya yaitu pencetakan SKPD/STNK. Kemudian petugas Bapenda yang menganggur memanggil wajib pajak untuk proses pengambilan SKPD/STNK dan juga pengambilan TNKB. Apabila berkas dinyatakan tidak lengkap petugas Bapenda dan petugas Bank Sumsel yang menganggur akan memanggil nomor antrian berikutnya.

Berdasarkan hasil pengamatan diperoleh rata-rata pelayanan pembayaran pajak yang berkasnya belum lengkap akan lebih lama jika dibandingkan dengan pelayanan pembayaran pajak yang berkasnya dinyatakan lengkap. Hal ini dikarenakan wajib pajak harus melengkapi berkasnya terlebih dahulu untuk bisa melanjutkan pada tahap berikutnya.

Hasil pengamatan di SAMSAT Oku Timur 1, diperoleh model antrian dan diagram alir pelayanan pembayaran pajak. Model antrian pelayanan pembayaran pajak di SAMSAT Oku Timur 1 dapat dituliskan lebih jelas sebagai berikut:

1. Wajib pajak datang.

2. Wajib pajak mengambil nomor antrian.

3. Petugas Bapenda yang menganggur memanggil nomor antrian wajib pajak untuk dilayani.

4. Petugas Bapenda memeriksa kelengkapan berkas membayar pajak.

5. Jika berkas lengkap maka wajib pajak akan diberikan formulir untuk diisi dan kemudian diarahkan untuk melakukan cek fisik kendaraan. Namun, jika berkas 


\section{N. Nurlela, et.al}

masih kurang lengkap maka wajib pajak harus melengkapi berkasnya terlebih dahulu.

6. Setelah cek fisik kendaraan maka petugas Bapenda akan memberikan berkas kepada petugas kepolisian.

7. Setelah itu dilakukan dilakukan input data oleh petuga Bapenda.

8. Petugas Bapenda yang menganggur memberikan berkas kepada petugas kepolisian untuk pengecekan ranmor.

9. Setelah pengecekan ranmor, petugas Bapenda akan mencetak dan melakukan pengecekan kutipan pembayaran pajak.

10. Setelah dilakukan pengecekan oleh petugas Bapenda akan dilakukan pengecekan SWDKLLJ oleh petugas Jasa Raharja.

11. Kemudian kutipan pembayaran pajak tersebut diserahkan kepada petugas Bank dan petugas Bank yang menganggur memanggil wajib pajak.

12. Petugas Bank Sumsel memberitahu nominal yang harus dibayarkan oleh wajib pajak.

13. Wajib pajak membayar pajak ke Bank Sumsel sesuai dengan nominal yang harus di bayarkan.

14. Petugas Bank berkewajiban untuk memberikan bukti pembayaran kepada wajib pajak untuk digunakan dalam pengambilan SKPD/STNK dan juga TNKB.

15. Setelah memperoleh bukti pembayaran wajib pajak langsung ke loket pelayanan dua untuk pengambilan SKPD/STNK dan juga TNKB yang sudah di cetak oleh petugas Bapenda.

16. Wajib pajak pulang.

\subsection{Model Jaringan Petri Net}

Dari sistem antrian yang diperoleh, dapat dibentuk model pelayanan pembayaran pajak kendaraan bermotor jenis 5 tahun yang disimulasikan ke dalam Petri Net dengan menggunakan Softwere WOPED 3.2.0. Model Petri Net dari Sistem Pelayanan Pembayaran Pajak Kendaraan Bermotor Jenis 5 Tahun terdiri dari 17 Places dan 15 transisi. Berikut adalah gambar model Petri Net dari Sistem Pelayanan Pembayaran Pajak Kendaraan Bermotor Jenis 5 Tahun.

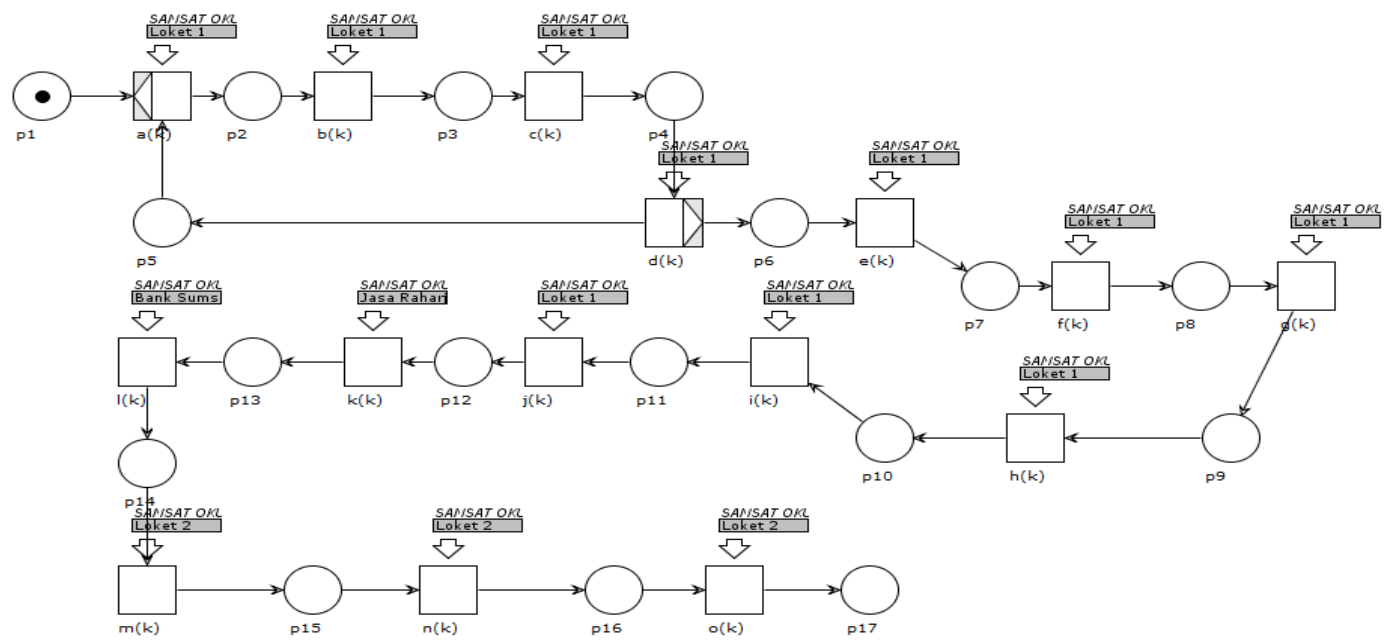

Gambar 1. Alur Petri Net sistem pembayaran pajak kendaraan bermotor jenis 5 tahun di SAMSAT Oku Timur 1

Adapun penjelasan untuk setiap Place dan transisi pada Gambar 1 adalah sebagai berikut: 
$\mathrm{a}(\mathrm{k}) \quad=$ menyatakan event kedatangan wajib pajak ke SAMSAT Oku Timur 1

$\mathrm{b}(\mathrm{k}) \quad=$ menyatakan event pengambilan nomor antrian

$\mathrm{c}(\mathrm{k}) \quad=$ menyatakan event pelayanan pembayaran pajak 5 tahun dimulai

$\mathrm{d}(\mathrm{k}) \quad=$ menyatakan event pengecekan berkas wajib pajak oleh petugas Bapenda

$\mathrm{e}(\mathrm{k}) \quad=$ menyatakan event pengisian formulir oleh wajib pajak

$\mathrm{f}(\mathrm{k}) \quad=$ menyatakan event pengecekan fisik kendaraan oleh petugas polisi

$\mathrm{g}(\mathrm{k}) \quad=$ menyatakan event input data oleh petugas polisi

$\mathrm{h}(\mathrm{k}) \quad=$ menyatakan event pengecekan ranmor oleh petugas polisi

$\mathrm{i}(\mathrm{k}) \quad=$ menyatakan event pencetakan pembayaran pajak 5 tahun oleh petugas Bapenda

$\mathrm{j}(\mathrm{k}) \quad=$ menyatakan event pengecekan pembayaran pajak 5 tahun oleh petugas Bapenda

$\mathrm{k}(\mathrm{k}) \quad=$ menyatakan event pengecekan SWDKLLJ (Sumbangan Wajib Dana

Kecelakaan Lalu Lintas) oleh Jasa Raharja.

$1(\mathrm{k}) \quad=$ menyatakan event pembayaran pajak 5 tahun ke Bank Sumsel

$\mathrm{m}(\mathrm{k})=$ menyatakan event pencetakan SKPD/STNK

$\mathrm{n}(\mathrm{k}) \quad=$ menyatakan event pengambilan SKPD/STNK

$\mathrm{o}(\mathrm{k}) \quad=$ menyatakan event pengambilan TNKB

P1 = menyatakan kondisi wajib pajak berada di SAMSAT Oku Timur 1

P2 = menyatakan kondisi wajib pajak mendapatkan nomor antrian

P3 = menyatakan kondisi wajib pajak berada di loket pelayanan 1

$\mathrm{P} 4=$ menyatakan kondisi wajib pajak memberikan berkas persyaratan

P5 = menyatakan kondisi petugas Bapenda yang menggangur

P6 = menyatakan kondisi petugas Bapenda memberikan formular pendaftaran

P7 = menyatakan kondisi kendaraan wajib pajak yang telah selesai dilakukan cek fisik

P8 = menyatakan kondisi berkas telah di input oleh petugas Bapenda

P9 = menyatakan kondisi wajib pajak menunggu

P10 = menyatakan kondisi wajib pajak menunggu

P11 = menyatakan kondisi wajib pajak menunggu

$\mathrm{P} 12=$ menyatakan kondisi wajib pajak menunggu

P13 = menyatakan kondisi petugas Bank Sumsel yang menganggur, memanggil wajib pajak untuk proses pembayaran

$\mathrm{P} 14$ = menyatakan kondisi wajib pajak memberikan bukti pembayaran kepada petugas Bapenda

P15 = menyatakan kondisi telah selesai SKPD/STNK

P16 = menyatakan kondisi telah terambilnya TNKB

P17 = menyatakan kondisi wajib pajak meninggalkan SAMSAT Oku Timur 1

Berikut akan ditunjukkan tabel hasil analisis simulasi token game pada softwere WOPED.

Tabel 1. Hasil Analisis Simulasi Token Game pada Softwere WOPED

\begin{tabular}{|c|c|c|c|c|}
\hline \multirow{12}{*}{$\begin{array}{l}\text { Qualitative } \\
\text { analysis }\end{array}$} & \multirow{8}{*}{$\begin{array}{c}\text { Structural } \\
\text { Analysis }\end{array}$} & \multirow{4}{*}{ Net Statics } & Places & 17 \\
\hline & & & Transitions & 15 \\
\hline & & & Operators & 2 \\
\hline & & & Arcs & 34 \\
\hline & & \multicolumn{2}{|c|}{ Wrongly used operators } & $\mathrm{Ya}$ \\
\hline & & \multicolumn{2}{|c|}{ Free-choice violations } & Ya \\
\hline & & \multicolumn{2}{|l|}{ S-Components } & Ya \\
\hline & & \multicolumn{2}{|c|}{ Wellstructuredness } & $\mathrm{Ya}$ \\
\hline & & \multicolumn{2}{|l|}{ Workflow net } & $\mathrm{Ya}$ \\
\hline & & \multicolumn{2}{|l|}{ Initial marking } & Ya \\
\hline & soundness & \multicolumn{2}{|l|}{ Boundness } & $\mathrm{Ya}$ \\
\hline & & \multicolumn{2}{|l|}{ Livenes } & Ya \\
\hline
\end{tabular}


Setelah dianalisis dengan Woped hasil seperti yang ditunjukkan pada gambar, bahwa Petri Net untuk proses pelayanan pembayaran sudah terpenuhi.

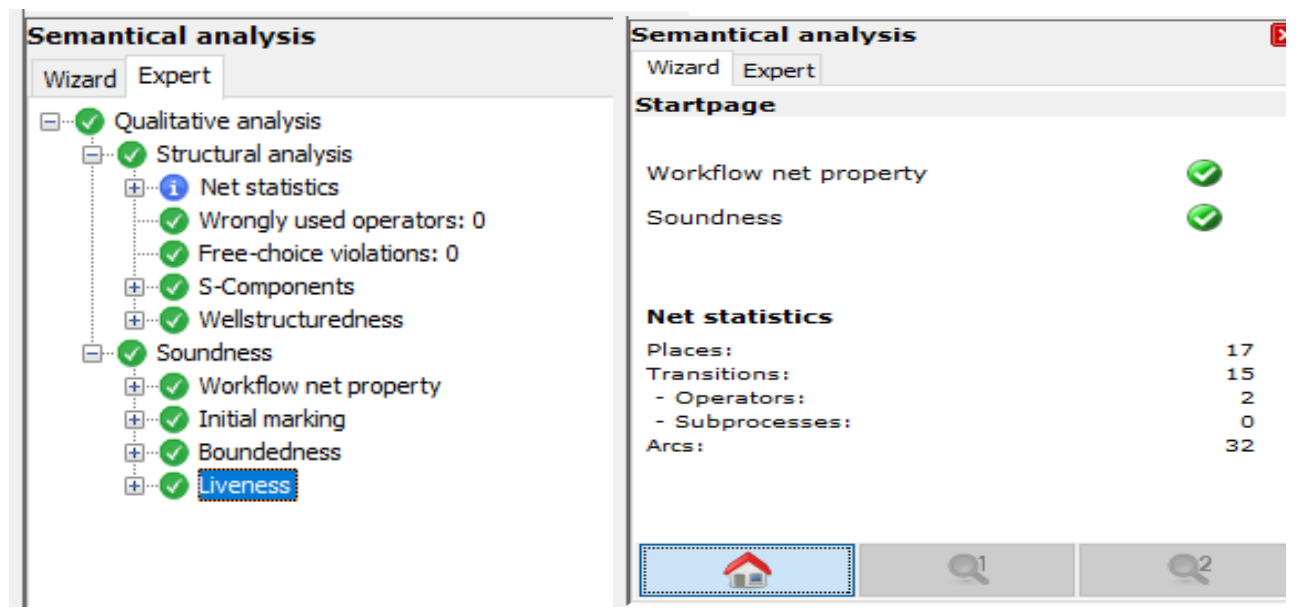

Gambar 2. Hasil analisis Structural Analysisis dan Soundness Petri Net Sistem

Selanjutnya dibahas tentang rata-rata waktu pelayanan pembayaran pajak kendaraan bermotor jenis 5 tahun di SAMSAT Oku Timur 1. Proses pertama dimulai dari loket pelayanan 1 dengan pengecekan berkas oleh petugas Bapenda, untuk pengecekan berkas rata-rata waktu yang dibutuhkan sekitar 2 menit. Proses kedua yaitu cek fisik kendaraan dengan rata-rata waktu yang dibutuhkan sekitar 5 menit. Proses ketiga yaitu input data dengan rata-rata waktu yang dibutuhkan sekitar 1 menit. Proses keempat yaitu pengecekan ranmor oleh petugas polisi dengan rata-rata waktu yang dibutuhkan sekitar 1 menit. Proses kelima yaitu mencetak kutipan pembayaran pajak dengan rata-rata waktu yang dibutuhkan sekitar 4 menit. Proses keenam yaitu pengecekan kutipan pembayaran pajak oleh petugas Bapenda dengan rata-rata waktu yang dibutuhkan sekitar 3 menit. Proses Ketujuh yaitu pengecekan Sumbangan Wajib Dana Kecelakaan Lalu Lintas (SWDKLLJ) oleh petugas Jasa Raharja dengan rata-rata waktu yang dibutuhkan sekitar 2 menit. Proses kedelapan yaitu pembayaran pajak ke Bank Sumsel dengan rata-rata waktu yang dibutuhkan sekitar 5 menit. Proses Kesembilan yang dilakukan di loket pelayanan 2 yaitu mencetak SKPD/STNK dengan ratarata waktu yang dibutuhkan sekitar 2 menit. Proses kesepuluh yaitu pengambilan SKPD/STNK dengan rata-rata waktu yang dibutuhkan sekitar 1 menit. Proses yang terakhir yaitu pengambilan TNKB dengan rata-rata waktu yang dibutuhkan sekitar 1 menit.

Waktu yang dibutuhkan untuk proses pelayanan akan berbeda antara wajib pajak yang sudah lengkap berkasnya dan yang belum lengkap. Untuk wajib pajak yang berkasnya belum lengkap akan ada penambahan waktu karena wajib pajak harus melengkapi persyaratan yang ada seperti membawa KTP asli dan STNK (Surat Tanda Nomor Kendaraan). Biasanya wajib pajak juga membawa fotokopi KTP karena syarat pembayaran pajak harus menyerahkan fotokopi KTP dan menunjukkan KTP asli. Jika persyaratan sudah lengkap, maka wajib pajak kembali ke kantor SAMSAT untuk melanjutkan proses pelayanan. Hasil analisis proses pembayaran pajak kendaraan bermotor disajikan pada Tabel 2 .

Dari Tabel 2 diperoleh waktu pelayanan pembayaran pajak kendaraan bermotor jenis 5 tahun yang telah melengkapi berkas lebih cepat selesai dengan rata-rata waktu pelayanan adalah 28 menit sedangkan yang belum melengkapi berkas lebih lama dengan rata-rata waktu pelayanan 36 menit. 
Tabel 2. Hasil analisis lamanya proses pelayanan pembayaran pajak kendaraan bermotor jenis 5 tahun

\begin{tabular}{llcc}
\hline \multirow{2}{*}{ No. } & \multicolumn{1}{c}{ Jenis Pelayanan } & \multicolumn{2}{c}{ Rata-rata waktu pelayanan (menit) } \\
\cline { 3 - 4 } & & $\begin{array}{c}\text { Berkas WP } \\
\text { Lengkap }\end{array}$ & $\begin{array}{c}\text { Berkas WP Belum } \\
\text { Lengkap }\end{array}$ \\
\hline 1. & Cek kelengkapan berkas & 2 & 10 \\
2. & Cek fisik kendaraan & 5 & 5 \\
3. & Input data & 1 & 1 \\
4. & Pengecekan ranmor & 2 & 2 \\
5. & Pencetakan kutipan pembayaran pajak & 4 & 4 \\
6. & Pengecekan kutipan pembayaran pajak & 3 & 3 \\
7. & Pengecekan SWDKLL & 2 & 2 \\
8. & Pembayaran pajak ke Bank Sumsel & 5 & 5 \\
9. & Mencetak SKPD/STNK & 2 & 2 \\
10. & Pengambilan SKPD/STNK & 1 & 1 \\
11. & Pengambilan TNKB & 1 & 1 \\
\hline Jumlah rata-rata waktu pelayanan & 28 & 36 \\
\hline
\end{tabular}

4. Kesimpulan

Sistem pelayanan pembayaran pajak kendaraan jenis 5 tahun dapat dimodelkan dengan model Petri Net sebanyak 17 place, 15 transisi, 2 operator, dan 34 arc dengan menggunakan softwere WOPED 3.2.0. Dari hasil pengamatan lamanya waktu proses pelayanan pembayaran pajak kendaraan jenis 5 tahun, dapat diketahui bahwa wajib pajak yang sudah melengkapi berkas persyaratan akan lebih cepat selesai dengan ratarata waktu 28 menit sedangkan wajib pajak yang belum melengkapi berkas persyaratan akan lebih lama dengan rata-rata waktu 38 menit.

\section{Ucapan Terima Kasih}

Ucapan terima kasih dan penghargaan disampaikan kepada UPTB Pengelolaan Pendapatan Daerah Wilayah Oku Timur 1 Provinsi Sumatera Selatan yang telah menfasilitasi pelakasanaan penelitian ini.

\section{Referensi}

[1] M. F. Rahmadana et al., Pelayanan Publik. Yayasan Kita Menulis, 2020.

[2] A. Halim, I. R. Bawono, and A. Dara, Perpajakan: Konsep, Aplikasi, Contoh, dan Studi Kasus. Jakarta: Salemba Empat, 2014.

[3] H. A. Taha, Riset Operasi, Jilid 2. Binarupa Aksara, 1996.

[4] J. L. Peterson, Teori Petri Net dan Pemodelan Sistem. New York: Pretince Hall, 1981.

[5] C. A. Petri, "Communication with Automata," Darmstadt Technical University, 1962.

[6] R. Munir, Matematika Diskrit. Bandung: Informatika, 2005.

[7] F. N. Wattimena, T. Pentury, and Y. A. Lesnussa, "Aplikasi Petri Net pada sistem pembayaran tagihan listrik PT. PLN (Persero) Rayon Ambon Timur," BAREKENG J. Ilmu Mat. dan Terap., vol. 6, no. 1, pp. 23-30, 2012. 
[8] I. Kabashkin, "Modelling of Regional Transit Multimodal Transport Accessibility with Petri Net Simulation," Procedia Comput. Sci., vol. 77, pp. 151157, 2015.

[9] I. Kabashkin, "Heuristic Based Decision Support System for Choice of Alternative Routes in the Large-Scale Transportation Transit System on the Base of Petri Net Model," Procedia Eng., vol. 134, pp. 359-364, 2016.

[10] A. Boussif and M. Ghazel, "A Diagnosis Study on a Train Passenger Access System using Petri Net Models," IFAC-PapersOnLine, vol. 51, no. 9, pp. 150-155, 2018.

[11] J. Zhoua and Reniers. G., "Petri net simulation of multi-department emergency response to avert domino effects in chemical industry accidents," Process Saf. Environ. Prot., vol. 146, pp. 916-926, 2021.

[12] J. Latorre-Biel, J. Faulín, A. A. Juan, and E. Jiménez-Macías, "Petri Net Model of a Smart Factory in the Frame of Industry 4.0," IFAC-PapersOnLine, vol. 51, no. 2, pp. 266-271, 2018.

[13] M. Gheibia, M. Karrabia, and M. Eftekhari, “Designing a smart risk analysis method for gas chlorination units of water treatment plants with combination of Failure Mode Effects Analysis, Shannon Entropy, and Petri Net Modeling," Ecotoxicol. Environ. Saf., vol. 171, pp. 600-608, 2019.

[14] Z. Jianfenga and G. Reniers, "Probabilistic Petri-net addition enabling decision making depending on situational change: The case of emergency response to fuel tank farm fire," Reliab. Eng. Syst. Saf., vol. 200, 2020.

[15] S. Guana, M. Nakamuraa, T. Shikanaib, and T. Okazaki, "Hybrid Petri nets modeling for farm work flow," Comput. Electron. Agric., vol. 62, no. 2, pp. 149158, 2008.

[16] C. Mahulea, E. Montijano, and M. Kloetzer, "Distributed Multirobot Path Planning in Unknown Maps Using Petri Net Models," IFAC-PapersOnLine, vol. 53, no. 2, pp. 2063-2068, 2020.

[17] Y. Geab, X. Xinga, and Q. Cheng, "Simulation and analysis of infrastructure interdependencies using a Petri net simulator in a geographical information system," Int. J. Appl. Earth Obs. Geoinf., vol. 12, no. 6, pp. 419-430, 2010.

[18] W. Yu, Z. Ding, L. Liu, X. Wang, and R. D. Crossleye, "Petri net-based methods for analyzing structural security in e-commerce business processes," Futur. Gener. Comput. Syst., vol. 109, pp. 611-620, 2020.

[19] P. J. Mitrevski and I. S. Hristoski, "Behavioral-based performability modeling and evaluation of e-commerce systems," Electron. Commer. Res. Appl., vol. 13, no. 5, pp. 320-340, 2014.

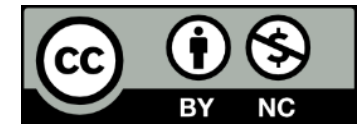

This article is an open-access article distributed under the terms and conditions of the Creative Commons Attribution-NonCommercial 4.0 International License. Editorial of JJoM: Department of Mathematics, Universitas Negeri Gorontalo, Jln. Prof. Dr. Ing. B.J. Habibie, Moutong, Tilongkabila, Kabupaten Bone Bolango, Provinsi Gorontalo 96119, Indonesia. 